\title{
Intra Peritoneal Instillation of Bupivacaine or Bupivacaine plus Magnesium Sulphate or Bupivacaine plus Dexamethasone on Post-Operative Pain after Laparoscopic Cholecystectomy: A Randomized Controlled Study
}

\author{
Alshefaa A. Zahra, Khaled M. Abo-Elenin, Elham M. El-Fiky, Zeinab A. Kasemy, Ahmed M. Helwa \\ Department of Anesthesiology and Intensive Care Faculty of Medicine, Menoufia University, Menoufia, Egypt \\ *Corresponding author: Alshefaa A. Zahra, Mobile: (+20) 01004887288, E-Mail: shefaaali20@ gmail.com
}

\begin{abstract}
Background: Laparoscopic cholecystectomy as opposed to open cholecystectomy is currently the most accepted surgical technique for cholelithiasis. Intraperitoneal administration of some drugs can be effective for pain relief after laparoscopic surgery. Intraperitoneal instillation of local anesthetics and opioids is gaining popularity for better pain relief.

Objectives: To compare the effect of adding dexamethasone or magnesium sulphate to bupivacaine on quality and duration of analgesia after intra-peritoneal instillation after laparoscopic cholecystectomy.

Patients and methods: Our prospective study was conducted on sixty patients with ASA physical status I or II. Their ages ranged between 18-60 years scheduled for laparoscopic cholecystectomy under general anesthesia in Menoufia University Hospitals. Patients were randomly divided into three groups, 20 patients each. Patients in group B (bupivacaine group): received $25 \mathrm{ml} 0.25 \%$ bupivacaine. Group M (Magnesium sulphate group) received $20 \mathrm{ml} 0.25 \%$ bupivacaine and $5 \mathrm{ml}(500 \mathrm{mg})$ magnesium sulphate. Group D (Dexamethasone group) received $20 \mathrm{ml} 0.25 \%$ bupivacaine and $2 \mathrm{ml}(8 \mathrm{mg})$ dexamethasone completed to $25 \mathrm{ml}$ with $3 \mathrm{ml}$ normal saline.

Results: First time of analgesia was significantly longer among magnesium group than dexamethasone group and bupivacaine group $(\mathrm{p}<0.05)$. Nalbuphine consumption in $24 \mathrm{hrs}$, was higher among bupivacaine group followed by dexamethasone group then magnesium group $(\mathrm{p}<0.05)$. Also, VAS score was significantly higher in bupivacaine group at 4 hour than other groups and, at 6-hour it was higher in dexamethasone group and bupivacaine group with no significant difference but highly significantly more than magnesium. In magnesium group VAS score was low over 24 hours.

Conclusion: Our study found that magnesium sulphate is a good additive than dexamethasone when combined with bupivacaine in intra-peritoneal instillation as it prolonged the duration of analgesia and reduced postoperative pain scores and nalbuphine consumption after laparoscopic cholecystectomy.
\end{abstract}

Keywords: Laparoscopic cholecystectomy, Intra-peritoneal instillation, Bupivacaine, Magnesium sulphate, Dexamethasone.

\section{INTRODUCTION}

Laparoscopic cholecystectomy as opposed to open cholecystectomy is currently the most accepted surgical technique for cholelithiasis ${ }^{(1)}$. Laparoscopic procedures have many advantages over open procedures such as lesser hemorrhage, better cosmetic results, lesser post-operative pain, and shorter recovery time, leading to shorter hospital stay and less expenditure ${ }^{(2)}$.

There is a significant difference in the quality of pain related to laparoscopic surgery as compared to laparotomy. The pain after laparotomy is mostly parietal whereas it is more of visceral pain following laparoscopic cholecystectomy ${ }^{(3)}$. Characteristically, the pain following laparoscopic cholecystectomy is highly variable in intensity and duration and is largely unpredictable ${ }^{(4)}$. Pain results from stretching of the intra-abdominal cavity ${ }^{(5)}$, peritoneal inflammation, and diaphragmatic irritation caused by residual carbondioxide in the peritoneal cavity ${ }^{(6)}$. Many methods have been proposed to relieve post-operative pain following laparoscopic cholecystectomy ${ }^{(7)}$. Intra-peritoneal administration of some drugs can be effective for pain relief after laparoscopic surgery. Intra-peritoneal instillation of local anesthetics and opioids is gaining popularity for better pain relief ${ }^{(\mathbf{8})}$.

The local anesthetic agents provide antinociception by affecting nerve membrane-associated proteins and by inhibiting the release and action of prostaglandins, which stimulate the nociceptors and cause inflammation ${ }^{(9)}$. Absorption from a large peritoneal surface may be the mechanism of analgesia (10). Magnesium inhibits calcium entry into the cell through a noncompetitive blockade of the N-methyl-d aspartate (NMDA) receptor ${ }^{(\mathbf{1 1})}$. Magnesium is also a physiological calcium antagonist at different voltagegated channels (12). Administration of magnesium sulfate $\left(\mathrm{MgSO}_{4}\right)$ through different routes has been used in anesthetic practice for decreasing perioperative pain. $\mathrm{MgSO}_{4}$ also has been used to attenuate the adverse hemodynamic changes associated with pneumoperitoneum and improve the quality of recovery (13).

Steroid injection produces a degree of vasoconstriction, so one theory suggests that the drug acts by reducing local anesthetic absorption. Another theory tells that dexamethasone potentiates the activity of inhibitory potassium channels on nociceptive C- 
fibers (via glucocorticoid receptors), thereby decreasing their activity ${ }^{(14)}$.

\section{AIM OF THE WORK}

The primary outcome to determine the first time to request analgesia after intra-peritoneal instillation of bupivacaine or bupivacaine plus magnesium sulphate or bupivacaine plus dexamethasone on post-operative pain after laparoscopic cholecystectomy, and to assess post-operative pain with VAS score, analgesic consumption, incidence of complications and to measure hemodynamic changes.

\section{PATIENTS AND METHODS}

60 healthy patients of ASA I \& II scheduled for laparoscopic cholecystectomy of both sexes were enrolled in this study and were randomly divided into three equal groups (20 patients each) to receive bupivacaine (group B), bupivacaine plus $\mathrm{MgSO}_{4}$ (group $\mathrm{M}$ ), and bupivacaine plus Dexamethasone (group D). They were aged between 18 and 60 years.

Exclusion criteria: Patients with disturbed conscious level, hemodynamic instability, impaired renal or hepatic function, allergy to any of the drugs used in the study, acute cholecystitis, patients with severe cardiac, respiratory, and neurological diseases, those in whom procedure was converted to open cholecystectomy and in whom abdominal drain was put.

Randomization of patients was made by computer-generated program into three equal parallel groups (20 patients each). Group B received $25 \mathrm{ml}$ $0.25 \%$ bupivacaine. Group $\mathrm{M}$ received $20 \mathrm{ml} 0.25 \%$ bupivacaine and $5 \mathrm{ml}(500 \mathrm{mg})$ magnesium sulphate. Group D (20 patients) received $20 \mathrm{ml} \quad 0.25 \%$ bupivacaine and $2 \mathrm{ml}(8 \mathrm{mg})$ dexamethasone completed to $25 \mathrm{ml}$ with $3 \mathrm{ml}$ normal saline.

Pre-operative detailed history, general physical examination and relevant systemic examination of all the patients was done following all standard protocols and precautions. Routine investigations such as $\mathrm{CBC}$, urine analysis, liver function tests, serum electrolytes, random blood sugar, and electrocardiogram were performed and analyzed in detail prior to procedure following all standard precautions and protocols required. Before operation, the patients were instructed to use a $10 \mathrm{~cm}$ visual analogue score (VAS) (endpoints labeled 'no pain' and 'worst possible pain'). Incisional pain was defined as superficial pain in the abdominal wall, or wound pain. Intra-abdominal pain was defined as deep, dull, and difficult to localize pain inside the abdomen, or resembling biliary colic. Shoulder pain was defined as pain in the shoulder.

On arrival at operation room (OR), routine intraoperative monitoring (ECG, noninvasive blood pressure, pulse oximetry, and capnography were established. General anesthesia was induced with intravenous fentanyl (1-2 $\mu \mathrm{g} / \mathrm{kg})$, propofol $(2.0 \mathrm{mg} / \mathrm{kg})$ and atracurium $(0.5 \mathrm{mg} / \mathrm{kg})$, then orotracheal intubation. Patients were maintained with $50 \% \mathrm{O}_{2}$ and $50 \%$ air, 0.5-
$1 \mathrm{vol} \%$ isoflurane $1 \mathrm{MAC}$, and $0.1 \mathrm{mg} / \mathrm{kg}$ atracurium time scheduled for maintenance of muscle relaxation. Minute ventilation was adjusted to keep end-tidal $\mathrm{PCO}_{2}$ at $35-45 \mathrm{mmHg}$. After anesthesia induction, pneumoperitoneum was created by insufflation of $\mathrm{CO}_{2}$ to maintain intra-abdominal pressure between 12 and 15 $\mathrm{mmHg}$ through the surgical procedure.

At the end of the surgery, residual neuromuscular blockade was reversed with neostigmine $0.05 \mathrm{mg} / \mathrm{kg}$ and atropine $0.01 \mathrm{mg} / \mathrm{kg}$ intravenously after return of protective reflexes. Studied drugs were prepared by an anesthesiologist not involved in the study. Anesthesiologist who observed the patient and surgeon was unaware of the study group until the end of the study. At the end of the surgery, the study solution was given intraperitoneally before removal of trocar in Trendelenberg's position, into the hepatodiaphragmatic space, on gall bladder bed and near and above hepatoduodenal ligament. After completion of the surgical procedure patients were transferred to the postanesthetic care unit (PACU). After achieving an Aldrete score of 9 or higher, patients were discharged from the PACU to an intermediate care unit for $24 \mathrm{~h}$.

All patients stayed in PACU for $2 \mathrm{~h}$ after the end of surgery. The intensity of post-operative pain was recorded for all the patients using VAS score at $0.5,1$, $2,4,6,12$ and $24 \mathrm{~h}$ after surgery and over all VAS score (mean of all VAS scores), (VAS score 0 - no pain, VAS score 10 - worst possible pain). Patients who reported VAS $\geq 3$ were given nalbuphine $(4 \mathrm{mg}$ ) intravenously as rescue analgesia. Patients were also be observed for post-operative nausea and vomiting. Patients who suffered nausea or vomiting were given ondansetron 4 $\mathrm{mg}$ IV. Time to the first request of analgesia (considering the extubation as time 0), VAS score, total dose of analgesia, adverse or side effects and hemodynamic changes over $24 \mathrm{~h}$ postoperatively were noted.

Sample size calculation, based on the results of pervious study Maharjan et al. ${ }^{(15)}$, the mean difference for time of 1st analgesic (hours) between the magnesium sulphate group and bupivacaine group was $2.47 \mathrm{hrs}$. The sample size was calculated at power $90 \%$ and CI $95 \%$ and it was 20 subjects per group. With a withdrawal/ non-evaluable subject rate of $10 \%$ a total 22 per group subjects were recruited. An equal number was recruited for bupivacaine plus dexamethasone as there was no study combined the three groups together.

\section{Ethical approval:}

An approval of the study was obtained from Menoufia University academic and ethical committee. Every patient signed an informed written consent for acceptance of the operation. This work has been carried out in accordance with The Code of Ethics of the World Medical Association (Declaration of Helsinki) for studies involving humans. 


\section{Statistical analysis}

The collected data were coded, processed and analyzed using the SPSS (Statistical Package for Social Sciences) version 22 for Windows ${ }^{\circledR}$ (IBM SPSS Inc, Chicago, IL, USA). Data were tested for normal distribution using the Shapiro Walk test. Qualitative data were represented as frequencies and relative percentages. Chi square test $\left(\chi^{2}\right)$ to calculate difference between two or more groups of qualitative variables. Quantitative data were expressed as mean \pm SD (Standard deviation). Independent samples t-test was used to compare between two independent groups of normally distributed variables (parametric data). $\mathrm{P}$ value $\leq 0.05$ was considered significant.

\section{RESULTS}

Demographic data of patients (age, sex and ASA classification) were comparable between both groups (table 1).

As regards first time of analgesia, it was significantly longer among magnesium group than other groups [(211.75 $\pm 60.0 \mathrm{~min}$ for bupivacaine group, $293.50 \pm 79.32 \mathrm{~min}$ for dexamethasone group and $525.75 \pm 145.5 \mathrm{~min}$ for magnesium group, $\mathrm{p}<0.05)$ ]. Nalbuphine consumption in $24 \mathrm{hrs}$ was significantly higher among bupivacaine (marcaine) group, followed by dexamethasone group than magnesium group, $(\mathrm{p}<$ 0.05) (table 2).
As regards postoperative visual analogue scale, at $0.5,1$ and 2 hours VAS was comparable between both groups but the difference was nonsignificant. At 4-hours, VAS showed higher values in marcaine group than magnesium and dexamethasone groups and the difference between them was significant $(\mathrm{P}<0.001)$. At 6-hour postoperative, VAS showed significantly higher values in marcaine group than magnesium group $(\mathrm{P}<0.05)$. Also, lower in marcaine than dexamethasone but the difference was nonsignificant $(\mathrm{P}=0.056)$. At 12 and 24 hours, VAS showed significantly higher values in marcaine group than the other groups $(\mathrm{P}<0.05)$ (table 3$)$.

Intraoperative MAP was comparable between studied groups as shown in table (4). As regards heart rate, it was non-significant between the studied groups at $0.5,1$ and 2 hours postoperative $(\mathrm{P}>0.05)$. At 4 -hour postoperative, heart rate showed higher values in marcaine group than other groups but the difference was non-significant $(\mathrm{P}<0.001)$. At 6 -hour postoperative, heart rate showed significantly higher values in marcaine group than magnesium group $(\mathrm{P}=0.005)$. Also, heart rate showed lower values in marcaine than dexamethasone but the difference was non-significant $(\mathrm{P}=0.064)$. At 12 and 24 hours, VAS showed higher values in marcaine group than in the other groups $(\mathrm{P}<$ 0.001) (table 5).

Table (1): Comparison between the studied groups according to demographic characteristics

\begin{tabular}{|c|c|c|c|c|c|c|c|c|c|}
\hline Variables & \multicolumn{2}{|c|}{$\begin{array}{l}\text { Marcaine } \\
(\mathbf{n}=\mathbf{2 0})\end{array}$} & \multicolumn{2}{|c|}{$\begin{array}{c}\text { Magnesium } \\
(\mathbf{n}=\mathbf{2 0})\end{array}$} & \multicolumn{2}{|c|}{$\begin{array}{c}\text { Dexamethasone } \\
(\mathbf{n}=\mathbf{2 0})\end{array}$} & Test of sig & $P$ value & $\begin{array}{c}\text { Post hoc } \\
\text { test }\end{array}$ \\
\hline \multirow[t]{2}{*}{$\begin{array}{l}\text { Age } \\
\text { Mean } \pm \text { SD } \\
\text { Range }\end{array}$} & \multicolumn{2}{|c|}{$\begin{array}{c}44.65 \pm 9.38 \\
28-59\end{array}$} & \multicolumn{2}{|c|}{$\begin{array}{c}43.60 \pm 8.41 \\
27-57 \\
\end{array}$} & \multicolumn{2}{|c|}{$\begin{array}{c}44.15 \pm 8.12 \\
27-58\end{array}$} & \multirow[t]{2}{*}{$\mathrm{F}=0.07$} & \multirow[t]{2}{*}{0.929} & $\begin{array}{l}\text { P1: } 0.703 \\
\text { P2: } 0.856 \\
\text { P3: } 0.841\end{array}$ \\
\hline & $\mathbf{N}$ & $\%$ & $\mathbf{N}$ & $\%$ & $\mathbf{N}$ & $\%$ & & & \\
\hline $\begin{array}{l}\text { Gender } \\
\text { Male } \\
\text { Female }\end{array}$ & $\begin{array}{c}5 \\
15\end{array}$ & $\begin{array}{l}25 \\
75\end{array}$ & $\begin{array}{c}6 \\
14\end{array}$ & $\begin{array}{l}30 \\
70\end{array}$ & $\begin{array}{c}7 \\
13\end{array}$ & $\begin{array}{l}35 \\
65\end{array}$ & $\chi 2=0.47$ & 0.788 & - \\
\hline $\begin{array}{l}\text { ASA } \\
\text { I } \\
\text { II }\end{array}$ & $\begin{array}{c}11 \\
9 \\
\end{array}$ & $\begin{array}{l}55 \\
45\end{array}$ & $\begin{array}{c}13 \\
7 \\
\end{array}$ & $\begin{array}{l}65 \\
35 \\
\end{array}$ & $\begin{array}{c}12 \\
8\end{array}$ & $\begin{array}{l}60 \\
40 \\
\end{array}$ & $\chi 2=0.41$ & 0.812 & - \\
\hline
\end{tabular}

ASA: American Society of Anesthesiologists, SD: stander deviation, $\quad$ F: ANOVA test X2 test: Chi-square test, *: significant P1: comparison Marcaine vs. Magnesium, P2: comparison Marcaine vs. Dexamethasone, P3: comparison Magnesium vs. Dexamethasone.

Table (2): Comparison between the studied groups according to first time of analgesia and nalbuphine consumption

\begin{tabular}{|l|c|c|c|c|c|c|}
\hline \multicolumn{1}{|c|}{ Variables } & $\begin{array}{c}\text { Marcaine } \\
(\mathbf{n = 2 0}) \\
\text { Mean } \pm \text { SD }\end{array}$ & $\begin{array}{c}\text { Magnesium } \\
(\mathbf{n = 2 0}) \\
\text { Mean } \pm \text { SD }\end{array}$ & $\begin{array}{c}\text { Dexamethasone } \\
(\mathbf{n = 2 0}) \\
\text { Mean } \pm \text { SD }\end{array}$ & $\begin{array}{c}\text { Test } \\
\text { of } \\
\text { sig }\end{array}$ & P value & Post hoc test \\
\hline $\begin{array}{l}\text { First time of } \\
\text { analgesia }\end{array}$ & $\begin{array}{c}211.75 \pm \\
60.05\end{array}$ & $525.75 \pm 145.55$ & $293.50 \pm 79.32$ & $\begin{array}{c}\mathrm{F}= \\
51.2 \\
2\end{array}$ & $0.001^{*}$ & $\begin{array}{c}\mathrm{P} 1,3:<0.001^{*} \\
\mathrm{P} 2: 0.014^{*}\end{array}$ \\
\hline $\begin{array}{l}\text { Nalbuphine } \\
\text { consumption in } \\
\text { 24 hrs. }\end{array}$ & $10.80 \pm 5.52$ & $3.80 \pm 4.58$ & $7.60 \pm 3.87$ & $\begin{array}{c}\mathrm{F}= \\
11.0 \\
8\end{array}$ & $0.001^{*}$ & $\begin{array}{c}\text { P } 2: 0.036^{*} \\
\mathrm{P} 3: 0.014^{*}\end{array}$ \\
\hline
\end{tabular}

SD: stander deviation, $\quad$ F: ANOVA test, *: significant, $\quad$ P1: comparison Marcaine vs. Magnesium, P2: comparison Marcaine vs. Dexamethasone, P3: comparison Magnesium vs. Dexamethasone 
Table (3): Comparison between the studied groups according to VAS score

\begin{tabular}{|c|c|c|c|c|c|c|}
\hline VAS score & $\begin{array}{c}\text { Marcaine } \\
(\mathrm{N}=20) \\
\text { Mean } \pm \text { SD }\end{array}$ & $\begin{array}{c}\text { Magnesium } \\
(\mathrm{N}=20) \\
\text { Mean } \pm \mathrm{SD}\end{array}$ & $\begin{array}{c}\text { Dexamethasone } \\
(\mathrm{N}=20) \\
\text { Mean } \pm \text { SD }\end{array}$ & $\mathbf{F}$ & $P$ value & Post hoc test \\
\hline $0.5 \mathrm{~h}$ & $0.75 \pm 0.28$ & $0.5 \pm 0.22$ & $0.58 \pm 0.06$ & 1.495 & 0.067 & $\begin{array}{l}\text { P1: } 0.077 \\
\text { P2: } 0.083 \\
\text { P3: } 0.15\end{array}$ \\
\hline $1 \mathrm{~h}$ & $1.3 \pm 0.58$ & $0.5 \pm 0.22$ & $0.65 \pm 0.75$ & 1.431 & 0.068 & $\begin{array}{l}\text { P1: } 0.067 \\
\text { P2: } 0.072 \\
\text { P3:250 }\end{array}$ \\
\hline $2 \mathrm{~h}$ & $1.50 \pm 1.00$ & $0.6 \pm 0.41$ & $0.78 \pm 0.85$ & 1.829 & 0.55 & $\begin{array}{l}\text { P1: } 0.053 \\
\text { P2: } 0.490 \\
\text { P3:062 }\end{array}$ \\
\hline $4 \mathrm{~h}$ & $4.60 \pm 1.05$ & $0.63 \pm 0.42$ & $0.80 \pm 1.39$ & 47.005 & $<0.001 * *$ & $\begin{array}{l}\text { P1,2: <0.001* } \\
\text { P3: } 0.350\end{array}$ \\
\hline $6 \mathrm{~h}$ & $2.11 \pm 1.60$ & $0.65 \pm 0.69$ & $2.35 \pm 1.53$ & 65.989 & $<0.001 * *$ & $\begin{array}{l}\text { P1,3: }<0.001^{*} \\
\text { P2: } 0.056\end{array}$ \\
\hline $12 \mathrm{~h}$ & $5.90 \pm 0.72$ & $1.00 \pm 0.72$ & $4.20 \pm 1.64$ & 99.389 & $<0.001 * *$ & $\begin{array}{l}\mathrm{P} 1,3:<0.001^{*} \\
\mathrm{P} 2: 0.037^{*}\end{array}$ \\
\hline $24 \mathrm{~h}$ & $6.50 \pm 0.69$ & $1.55 \pm 0.69$ & $5.00 \pm 1.12$ & 175.076 & $<0.001 * *$ & $\begin{array}{l}\text { P1,3: }<0.001^{*} \\
\text { P2: } 0.024^{*}\end{array}$ \\
\hline
\end{tabular}

VAS: visual analogue scale,

SD: stander deviation,

F: ANOVA test, *: significant, P1: comparison Marcaine vs. Magnesium, P2: comparison Marcaine vs. Dexamethasone, P3: comparison Magnesium vs. Dexamethasone

Table (4): Comparison between the studied groups according to (Mean Arterial Pressure)

\begin{tabular}{|c|c|c|c|c|c|c|c|}
\hline & Variables & $\begin{array}{c}\text { Marcaine } \\
(n=20) \\
\text { Mean } \pm \text { SD }\end{array}$ & $\begin{array}{c}\text { Magnesium } \\
(n=20) \\
\text { Mean } \pm \text { SD }\end{array}$ & $\begin{array}{c}\text { Dexamethas } \\
\text { one } \\
(n=20) \\
\text { Mean } \pm \text { SD }\end{array}$ & $\mathbf{F}$ & $\begin{array}{c}P \\
\text { value }\end{array}$ & Post hoc test \\
\hline \multirow{7}{*}{$\sum$} & $0.5 \mathrm{~h}$ & $85.65 \pm 5.66$ & $85.55 \pm 7.07$ & $84.40 \pm 6.34$ & 0.237 & 0.790 & $\begin{array}{l}\text { P1: } 0.961 \\
\text { P2: } 0.538 \\
\text { P3: } 0.571\end{array}$ \\
\hline & $1 \mathrm{~h}$ & $84.05 \pm 5.66$ & $84.85 \pm 6.88$ & $83.90 \pm 6.26$ & 0.132 & 0.877 & $\begin{array}{l}\text { P1: } 0.689 \\
\text { P2: } 0.940 \\
\text { P3: } 0.635\end{array}$ \\
\hline & $2 \mathrm{~h}$ & $85.35 \pm 6.67$ & $84.75 \pm 7.04$ & $84.55 \pm 6.22$ & 0.078 & 0.925 & $\begin{array}{l}\text { P1: } 0.776 \\
\text { P2: } 0.705 \\
\text { P3: } 0.925\end{array}$ \\
\hline & $4 \mathrm{~h}$ & $86.65 \pm 5.76$ & $85.60 \pm 6.77$ & $85.45 \pm 5.92$ & 0.225 & 0.799 & $\begin{array}{l}\text { P1: } 0.592 \\
\text { P2: } 0.541 \\
\text { P3: } 0.939\end{array}$ \\
\hline & $6 \mathrm{~h}$ & $87.65 \pm 4.75$ & $85.90 \pm 6.63$ & $86.40 \pm 5.82$ & 0.485 & 0.618 & $\begin{array}{l}\text { P1: } 0.343 \\
\text { P2: } 0.497 \\
\text { P3: } 0.786 \\
\end{array}$ \\
\hline & $12 \mathrm{~h}$ & $90.00 \pm 5.38$ & $86.05 \pm 6.88$ & $88.15 \pm 5.63$ & 2.170 & 0.123 & $\begin{array}{l}\text { P1: } 0.042 \\
\text { P2: } 0.334 \\
\text { P3: } 0.273\end{array}$ \\
\hline & $24 \mathrm{~h}$ & $91.10 \pm 4.86$ & $86.20 \pm 7.01$ & $89.80 \pm 5.51$ & 2.043 & 0.094 & $\begin{array}{l}\text { P1: } 0.540 \\
\text { P2: } 0.486 \\
\text { P3: } 0.057\end{array}$ \\
\hline
\end{tabular}

MAP: mean arterial pressure, SD: stander deviation, F: ANOVA test, *: significant, P1: comparison Marcaine vs. Magnesium, P2: comparison Marcaine vs. Dexamethasone, P3: comparison Magnesium vs. Dexamethasone 
Table (5): Comparison between the studied groups according to heart rate (HR)

\begin{tabular}{|c|c|c|c|c|c|c|c|}
\hline \multicolumn{2}{|c|}{ Variables } & $\begin{array}{c}\text { Marcaine } \\
(n=20) \\
\text { Mean } \pm \text { SD }\end{array}$ & $\begin{array}{c}\text { Magnesium } \\
(n=20) \\
\text { Mean } \pm \text { SD }\end{array}$ & $\begin{array}{c}\text { Dexamethaso } \\
\text { ne } \\
(\mathbf{n}=20) \\
\text { Mean } \pm \text { SD }\end{array}$ & $\mathbf{F}$ & $P$ value & Post hoc test \\
\hline \multirow{7}{*}{$\underline{\underline{z}}$} & $0.5 \mathrm{~h}$ & $67.80 \pm 4.57$ & $67.80 \pm 3.12$ & $69.90 \pm 3.37$ & 2.099 & 0.132 & $\begin{array}{l}\text { P1: } 1.00 \\
\text { P2: } 0.081 \\
\text { P3: } 0.081\end{array}$ \\
\hline & $1 \mathrm{~h}$ & $69.05 \pm 4.19$ & $68.15 \pm 2.62$ & $70.65 \pm 3.82$ & 2.470 & 0.094 & $\begin{array}{l}\text { P1: } 0.433 \\
\text { P2: } 0.166 \\
\text { P3: } 0.320\end{array}$ \\
\hline & $2 \mathrm{~h}$ & $70.20 \pm 4.59$ & $68.05 \pm 2.37$ & $70.85 \pm 4.53$ & 1.720 & 0.485 & $\begin{array}{l}\text { P1: } 0.140 \\
\text { P2: } 0.981 \\
\text { P3: } 0.120\end{array}$ \\
\hline & $4 \mathrm{~h}$ & $76.45 \pm 4.38$ & $68.30 \pm 2.97$ & $71.20 \pm 5.06$ & 9.644 & $<0.001 *$ & $\begin{array}{l}\mathrm{P} 1:<0.001^{*} \\
\mathrm{P} 2: 0.042^{*} \\
\mathrm{P} 3: 0.073\end{array}$ \\
\hline & $6 \mathrm{~h}$ & $73.40 \pm 4.17$ & $68.50 \pm 2.44$ & $75.15 \pm 5.45$ & $\begin{array}{c}19.88 \\
7\end{array}$ & $<0.001 *$ & $\begin{array}{l}\text { P1: } 0.005^{*} \\
\text { P2: } 0.064 \\
\text { P3: }<0.001 *\end{array}$ \\
\hline & $12 \mathrm{~h}$ & $80.50 \pm 3.90$ & $69.20 \pm 2.65$ & $78.20 \pm 5.63$ & $\begin{array}{c}39.64 \\
9\end{array}$ & $<0.001 *$ & $\begin{array}{l}\text { P1,3: } \\
<0.001 * \\
\text { P2: } 0.092\end{array}$ \\
\hline & $24 \mathrm{~h}$ & $83.20 \pm 4.02$ & $68.90 \pm 2.69$ & $80.75 \pm 4.97$ & $\begin{array}{c}72.88 \\
8\end{array}$ & $<0.001 *$ & $\begin{array}{l}\text { P1,3: } \\
<0.001 * \\
\text { P2: } 0.058\end{array}$ \\
\hline
\end{tabular}

HR: heart rate, SD: stander deviation $\quad$ F: ANOVA test, *: significant P1: comparison Marcaine vs. Magnesium, P2: comparison Marcaine vs. Dexamethasone P3: comparison Magnesium vs. Dexamethasone

\section{DISCUSSION}

Different techniques have been implemented to decrease postoperative pain following laparoscopic cholecystectomy. Intra-peritoneal instillation of bupivacaine with or without adjuvants is one of popular modalities used to prevent post-operative pain. Various drugs are used in combination with local anesthetics to help reduce onset of effect, prolong the duration of action and to increase the chance of successful blockade. Toward these ends, a number of studies have been conducted with varying results (16). Many adjuvants like epinephrine, clonidine, opioids, ketamine and midazolam were combined with local anesthetics to prolong the duration of analgesia. However, the glucocorticoid (dexamethasone) has been shown to be effective in a small number of preclinical and clinical studies ${ }^{(17)}$. Magnesium $(\mathrm{Mg})$, the fourth most abundant cation in the body and the second most abundant intracellular cation, considered as a physiological blocker of N-Methyl-D-aspartate (NMDA) receptors. Magnesium (Mg) has anti nociceptive effects due to its antagonistic effect of NMDA receptors ${ }^{(\mathbf{1 8})}$.

Our study aimed to compare dexamethasone versus magnesium sulphate as additive to bupivacaine in intraperitoneal instillation on pain management after laparoscopic cholecystectomy. Sixty patients with ASA physical status I- II, aged from 18-60 years were included in the study and randomly divided into 3 groups, twenty patients for each group. Group B [bupivacaine (marcaine) group as control group], group $M$ (bupivacaine plus magnesium) and group D (bupivacaine plus dexamethasone). Our primary outcome measure was duration of analgesia starting from local anesthetic injection till the first call for analgesia, which was longer in $\mathrm{Mg}$ group. Secondary measures were post-operative hemodynamics, postoperative VAS, postoperative nalbuphine consumption in the first 24 hours and postoperative complications. Age, ASA status and gender were comparable between both groups. As regards duration of analgesia, it was prolonged in dexamethasone group than bupivacaine group and in magnesium group than other two groups. As regards first call for analgesia, it was at $211.75 \pm 60.0 \mathrm{~min}$ for bupivacaine group, 293.50 $\pm 79.32 \mathrm{~min}$ for dexamethasone group and $525.75 \pm$ $145.5 \mathrm{~min}$ for magnesium group. Postoperative nalbuphine consumption was significantly lower in magnesium group. All patients in control group and nearly in dexamethasone group received nalbuphine as analgesic in postoperative 24 hours while half of patients only needed nalbuphine in magnesium group.

As regards VAS score we found that it was significantly higher in bupivacaine group at 4 hours than in dexamethasone and magnesium groups and most of patients called for analgesia. At 6-hours we found that it was higher in dexa group and bupivacaine group with non-significant difference but highly significantly more 
than magnesium and most of patients required analgesia. In magnesium group, VAS score was low over 24 hours. Supporting our results are the results of Shelly et $\boldsymbol{a l}$. ${ }^{(19)}$ where their study was conducted on sixty-five women belonging to American Society of Anesthesiologists physical status 1 or 2 , aged between 35 and 70 years, scheduled for total abdominal hysterectomy under subarachnoid block. Patients in group $\mathrm{B}(n=32)$ received $18 \mathrm{~mL} 0.25 \%$ bupivacaine (45 mg) with $2 \mathrm{ml}$ normal saline (NS), whereas those in group $\mathrm{B} \& \mathrm{M}(n=33)$ received $18 \mathrm{~mL} 0.25 \%$ bupivacaine (45 mg) with $1.5 \mathrm{~mL}\left(150 \mathrm{mg}\right.$ ) $\mathrm{MgSO}_{4}$ and $0.5 \mathrm{~mL} \mathrm{NS}$ in the ultrasound (USG)-guided TAP block performed on each side after the completion of the surgery under SAB. They reported that addition of $\mathrm{MgSO}_{4}$ to bupivacaine in a dose of $150 \mathrm{mg}$ led to lower VAS pain scores, prolongation of analgesia and less requirement of rescue analgesia. Mahrajan ${ }^{(15)}$ in a study on 60 patients of (ASA) physical status I and II of 18-65 years undergoing laparoscopic surgery in the abdomen were randomly divided into two groups of 30 each to be administered one of the following intraperitoneal instillations: "bupivacaine group" received $30 \mathrm{ml}$ of $0.25 \%$ bupivacaine not exceeding the dose $2.0 \mathrm{mg} / \mathrm{kg}$ and "magnesium sulphate group" $0.25 \%$ bupivacaine $30 \mathrm{ml}$ along with $50 \mathrm{mg} / \mathrm{kg}$ of magnesium sulphate. They found that the combined instillation of bupivacaine and magnesium sulphate into the peritoneal cavity at the end of laparoscopic surgery rendered patients to be better in pain control and less consumption of analgesics in first 24 hours compared to sole bupivacaine group.

Al-Refaey et al. ${ }^{(20)}$ mentioned in their study, on ninety patients of ASA I and II who were planned for transversus abdominis plane block after laparoscopic cholecystectomy. They were divided into three groups: Control group, bupivacaine group and bupivacaine plus magnesium group. They reported that Adding $\mathrm{MgSO}_{4}$ as an adjuvant to bupivacaine in TAP block during anesthesia for laparoscopic cholecystectomy improved postoperative analgesia in the form of increased duration, decreased analgesic requirements and PONV. Haghighi et al. ${ }^{(21)}$ in a randomized double blind study about the effect of magnesium sulfate on sensory and 'motor axillary plexus blockade. They concluded that addition of magnesium sulfate to lidocaine increased the duration of motor and sensory axillary block in the upper extremities during surgeries when compared to the use of lidocaine alone. Also, Abd-Elsalam et al. (22) concluded in a randomized, double-blinded clinical trial included 60 women undergoing total abdominal hysterectomy who were divided into 2 groups (30 patients per group). Group I received a TAP block with $20 \mathrm{ml}$ per side of $0.25 \%$ bupivacaine plus $2 \mathrm{ml}$ magnesium sulphate $10 \%$ (200 mg). Group II received a TAP block with $20 \mathrm{ml}$ per side of $0.25 \%$ bupivacaine. They found that the mean total morphine consumption over the first 24 hours postoperatively was significantly lower in group I ( $7.63 \pm 2.93 \mathrm{mg})$ than in group II (16.20 $\pm 3.24 \mathrm{mg})(\mathrm{P}<0.001)$. Another study done by Dogru et al. ${ }^{(23)}$ on adding magnesium to levobupivacaine for axillary brachial plexus block in AV fistula surgery. They found that motor and sensory block onset times were statistically decreased in group with magnesium sulphate. Bondok and Abd El-Hady ${ }^{(24)}$ studied the effect of intra-articular magnesium in knee arthroscopy, and showed that magnesium resulted in a significant decrease in the postoperative VAS in the first $24 \mathrm{~h}$, which became less significant thereafter. In addition, there was significant decrease in the dose of postoperative rescue analgesia with a longer delay in the need for that analgesia, concluding that intra-articular magnesium could be a useful alternative for postoperative analgesia. Starvani et al. ${ }^{(25)}$ found that intraperitoneal injection of hydrocortisone in combination with bupivacaine before gas insufflation in laparoscopic cholecystectomy can reduce postoperative pain better than bupivacaine alone. Paramaswamy et al. ${ }^{\text {(26) }}$ conducted a study on 120 patients with isolated hand and forearm injuries who were divided into three equal groups. Ultrasound guided axillary brachial plexus block was performed in patients in group $\mathrm{C}$ with $30 \mathrm{~mL}$ of $0.375 \%$ bupivacaine plus $2 \mathrm{~mL}$ of normal saline, group D with $30 \mathrm{~mL}$ of $0.375 \%$ bupivacaine plus $8 \mathrm{mg}$ dexamethasone and group $\mathrm{K}$ with $30 \mathrm{~mL}$ of $0.375 \%$ bupivacaine plus $30 \mathrm{mg}$ ketorolac. They found that dexamethasone and ketorolac as adjuvant to bupivacaine in axillary plexus blocks significantly prolonged analgesia and duration of motor and sensory block. These effects were more enhanced with dexamethasone than ketorolac. Additionally, Naghipour et al. ${ }^{(27)}$ conducted a study on seventy two adult patients scheduled for elective abdominal or thoracic surgery under epidural anesthesia. They were randomly allocated into two groups to receive either bupivacaine $(0.5 \%)$ - fentanyl $(50 \mu \mathrm{g})$ and dexamethasone $(8 \mathrm{mg})$ in lumbar or thoracic epidural anesthesia or bupivacaine-fentanyl and normal saline via epidural catheter. This study revealed that dexamethasone added to bupivacaine-fentanyl solution in epidural analgesia prolonged the duration of analgesia in abdominal or thoracic surgery.

Regarding effect of magnesium over dexamethasone, Gaballah et al. ${ }^{(28)}$ conducted a trial on patients who were included to undergo laparoscopic unilateral ovarian cystectomy to assess the efficacy of intraperitoneal different combinations for postoperative pain relief. they found that intraperitoneal bupivacainemagnesium combination provides better analgesia and reduces postoperative morphine consumption than bupivacaine-hydrocortisone or magnesiumhydrocortisone combinations. Against our result, Mahgoub (29) compared the duration of postoperative analgesia after adding either magnesium sulfate or dexamethasone to levobupivacaine for performing supraclavicular brachial plexus block for upper-limb surgeries. They found that no significant differences were observed between group D (dexamethasone was 
added to levobupivacaine) and group $\mathrm{M}$ (which was given magnesium sulfate along with levobupivacaine) with respect to blood pressure and heart rate. Also, Hamed et al. ${ }^{(30)}$ stated in their study that when dexamethasone and magnesium sulfate were added to bupivacaine in ultrasound guided supraclavicular plexus block, both of them proved to prolong the duration of block and the analgesia time, both of them fasten the sensory block onset time, but dexamethasone was significantly more effective in prolonging the analgesia duration and the block duration. Dexamethasone shortens the motor block onset time while magnesium does not enhance the motor block onset time.

As regards postoperative complications, no significant differences were observed between the groups, nearly same number of patients among groups experienced nausea or vomiting.

As regards hemodynamics, MAP measurements were comparable between the groups and there was no significant difference. HR was comparable among groups with no difference at $0.5,1$ and 2 hours. At 4- hours, there was higher in marcaine group than in the other two groups. At 6-hours, it was higher in dexamethasone and marcaine groups than in magnesium group but the difference between them was non-significant. Finally, there was a lack in the studies that previously used dexamethasone and magnesium as adjuvant to local anesthetics in intraperitoneal injection but our results correlated with studies where dexamethasone or magnesium was used separately or in other peripheral nerve blocks.

\section{CONCLUSION}

Magnesium sulphate is a good additive than dexamethasone when combined with bupivacaine in intraperitoneal instillation after laparoscopic cholecystectomy as it prolonged the duration of analgesia and reduced postoperative pain scores and nalbuphine consumption.

\section{REFERENCES}

1. Kim T, Kang H, Park J et al. (2010): Intra-peritoneal ropivacaine instillation for postoperative pain relief after laparoscopic cholecystectomy. J Korean Surg Soc., 79: 130-6.

2. Bisgaard T, Kehlet H, Rosenberg J (2001): Pain and convalescence after laparoscopic cholecystectomy. Eur J Surg., 167: 84-96.

3. Golubovic S, Golubovic V, Cindric-Stancin M et al. (2009): Intraperitoneal analgesia for laparoscopic cholecystectomy: Bupivacaine versus bupivacaine with tramadol.

Coll

Antropol., 33: 299-302.

4. Bisgaard $\mathbf{T}$ (2006): Analgesic treatment after laparoscopic cholecystectomy: A critical assessment of the evidence. Anesthesiology, 104: 835-46.

5. Gupta R, Bogra J, Kothari N et al. (2010): Postoperative analgesia with intraperitoneal fentanyl and bupivacaine: A randomized control trial. Can $\mathbf{J}$ Med., 10: 1-11.
6. Esmat M, Elsebae M, Nasr M et al. (2006): Combined low pressure pneumoperitoneum and intraperitoneal infusion of normal saline for reducing shoulder tip pain following

laparoscopic cholecystectomy. World J Surg., 30: 196973.

7. El-Labban G, Hokkam E, El-Labban M et al. (2011): Intra-incisional Vs intraperitoneal infiltration of local anaesthetic for controlling early post-laparoscopic cholecystectomy pain. J Minim Access Surg., 7: 173-7.

8. Shabir S, Saleem B, Hakim A et al. (2011): Postoperative analgesia in laparoscopic cholecystectomy: a comparative study using bupivacaine instillation and infiltration versus parenteral analgesia (tramadol). The Internet Journal of Anaesthesiology, 29: 2-8.

9. Esmat M, Elsebae M, Nasr M et al. (2006): Combined low pressure pneumoperitoneum and intraperitoneal infusion of normal saline for reducing shoulder tip pain following

laparoscopic cholecystectomy. World J Surg., 30: 196973.

10. Marks J, Ata B, Tulandi T (2012): Systematic review and metaanalysis of intraperitoneal instillation of local anesthetics for reduction of pain after gynecologic laparoscopy. $\mathrm{J}$ Minim Invasive Gynecol., 19: 545-553.

11. Hernández-Palazón J, Tortosa J, Nuño de la Rosa $V$ et al. (2003): Intraperitoneal application of bupivacaine plus morphine for 12 pain relief after laparoscopic cholecystectomy. Eur J Anaesthesiol., 20: 891-896.

12. Ryu J, Kang M, Park K et al. (2007): Effects of magnesium sulphate on intraoperative anesthetic requirements and postoperative analgesia in gynecology patients receiving total intravenous anesthesia. Br J Anaesth., 100: 397-403.

13. Edmundas S, Rokas $L$ (2002): Use of magnesium sulphate in anesthesiology. Medicina (Kaunas), 38: 695698.

14. Attardi B, Takimoto $K$, Gealy $R$ et al. (1993): Glucocorticoid induced up-regulation of a pituitary potassium channel mRNA in vitro and in vivo. Receptors Channels, 1: 287-93.

15. Maharjan S, Shrestha S (2012): Intraperitoneal magnesium sulphate plus bupivacaine for pain relief after laparoscopic cholecystectomy. J Kathmandu Med Coll., 1: 21-25.

16. Hayes M, Paterson D (1921): Experimental development of the graphic rating method. Psychol Bull., 18: 98-99.

17. Abrahams S, Aziz F, Fu F et al. (2009): Ultrasound guidance compared with electrical neurostimulation for peripheral nerve block: a systematic review and metaanalysis of randomized controlled trials. British Journal of Anaesthesia, 102(3):408-417.

18. Hwang $\mathrm{Y}, \mathrm{Na} \mathrm{S}$, Jeon $\mathrm{T}$ et al. (2010): Infusion of magnesium sulphate during spinal anaesthesia improves postoperative analgesia. Br J Anaesth., 104 (1): 89-93.

19. Shelly R, Verma K, Jai $S$ et al. (2016): Magnesium sulphate as an adjuvant to bupivacaine in ultrasoundguided transversus abdominis plane block in patients scheduled for total abdominal hysterectomy under subarachnoid block. Indian J Anaesth., 60 (3): 174-179.

20. Al-Refaey K, Usama E, Al-Hefnawey E (2016): Adding magnesium sulfate to bupivacaine in 
transversus abdominis plane block for laparoscopic cholecystectomy: A single blinded randomized controlled trial. Saudi Journal of Anaesthesia, 2: 187191.

21. Haghighi M, Soleymanha M, Sedighinejad A et al. (2015): The effect of magnesium sulfate on motor and sensory axillary plexus blockade. Anesth Pain Med., 5 (1): 136-143.

22. Abd-Elsalam K, Fares K, Mohamed M et al. (2017): Efficacy of Magnesium Sulfate Added to Local Anesthetic in a Transversus Abdominis Plane Block for Analgesia Following Total Abdominal Hysterectomy: A Randomized Trial. Pain Physician, 20 (7): 641-647.

23. Dogru K, Yildirim D, Ulgey A et al. (2012): Adding magnesium to levobupivacaine for axillary brachial plexus block in arteriovenous fistule surgery. Bratisl Lek Listy, 113 (10): 607-9.

24. Bondok S, Abd El-Hady M (2006): Intra-articular magnesium is effective for postoperative analgesia in arthroscopic knee surgery. BJA: British Journal of Anaesthesia, 97 (3): 389-392.

25. Sabzi Sarvestani A, Amini S (2014): Intraperitoneal hydrocortisone plus bupivacaine administration for pain relief after laparoscopic cholecystectomy, a comparison with bupivacaine alone. Journal of Surgery and Trauma, 2 (1): 6-11.

26. Paramaswamy R, Venkata Mahipath S, Durairaj A et al. (2018): Comparison of Dexamethasone and
Ketorolac as an Adjuvant To Bupivacaine in Axillary Brachial Plexus Blocks for Isolated Hand and Forearm Injuries: A Randomised Double-Blind Prospective Study. Journal of Clinical \& Diagnostic Research, 12 (1): 155-161.

27. Naghipour B, Aghamohamadi D, Azarfarin R et al. (2013): Dexamethasone added to bupivacaine prolongs duration of epidural analgesia. Middle East $\mathbf{J}$ Anesthesiol., 22 (1): 53-7.

28. Gaballah K, Habeeb R, Abdallah S (2019): Efficacy of intraperitoneal bupivacaine, hydrocortisone, and magnesium sulfate in different combinations for pain relief after laparoscopic ovarian cystectomy: a doubleblind randomized controlled trial. Minerva Anestesiologica, 86 (1): 14-22.

29. Mahgoub A (2015): The addition of magnesium sulfate or dexamethasone to levobupivacaine for ultrasoundguided supraclavicular brachial plexus block for upperlimb surgery: a double-blinded comparative study. Research and Opinion in Anesthesia and Intensive Care, 2(4):116-122.

30. Hamed R, Osman N, Hassan W et al. (2016): Abstract PR295: Dexamethasone Versus Magnesium Sulfate As an additives to Bupivacaine in Ultrasound Guided Supraclavicular Brachial Plexus Blockade. Anesthesia \& Analgesia, 123 (3): 383-388. 